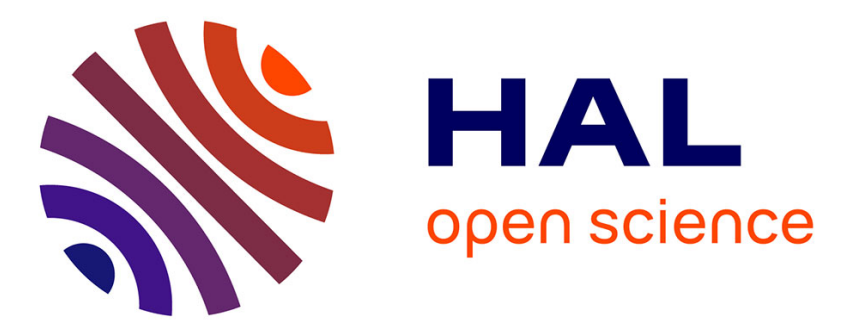

\title{
Gene-environment interactions in the study of asthma in the postgenomewide association studies era
}

\author{
Marta Rava, Lidwien A. M. Smit, Rachel Nadif
}

\section{To cite this version:}

Marta Rava, Lidwien A. M. Smit, Rachel Nadif. Gene-environment interactions in the study of asthma in the postgenomewide association studies era. Current Opinion in Allergy and Clinical Immunology, 2015, 15 (1), pp.70 - 78. 10.1097/ACI.0000000000000131 . inserm-01764301

\section{HAL Id: inserm-01764301 https://www.hal.inserm.fr/inserm-01764301}

Submitted on 11 Apr 2018

HAL is a multi-disciplinary open access archive for the deposit and dissemination of scientific research documents, whether they are published or not. The documents may come from teaching and research institutions in France or abroad, or from public or private research centers.
L'archive ouverte pluridisciplinaire HAL, est destinée au dépôt et à la diffusion de documents scientifiques de niveau recherche, publiés ou non, émanant des établissements d'enseignement et de recherche français ou étrangers, des laboratoires publics ou privés. 
archives-ouvertes

\title{
Gene-environment interactions in the study of asthma in the postgenomewide association studies era
}

\author{
Marta Rava, Lidwien Smit, Rachel Nadif, Lidwien A.M. Smit
}

\section{To cite this version:}

Marta Rava, Lidwien Smit, Rachel Nadif, Lidwien A.M. Smit. Gene-environment interactions in the study of asthma in the postgenomewide association studies era. Current Opinion in Allergy and Clinical Immunology, Lippincott, Williams \& Wilkins, 2015, 15 (1), pp.70 - 78. $<10.1097 /$ ACI.0000000000000131 > . <inserm-01764301>

\section{HAL Id: inserm-01764301 http://www.hal.inserm.fr/inserm-01764301}

Submitted on 11 Apr 2018

HAL is a multi-disciplinary open access archive for the deposit and dissemination of scientific research documents, whether they are published or not. The documents may come from teaching and research institutions in France or abroad, or from public or private research centers.
L'archive ouverte pluridisciplinaire HAL, est destinée au dépôt et à la diffusion de documents scientifiques de niveau recherche, publiés ou non, émanant des établissements d'enseignement et de recherche français ou étrangers, des laboratoires publics ou privés. 


\section{Gene-environment interactions in the study of asthma in the post-GWAS}

era

Marta Rava ${ }^{\mathrm{a}, \mathrm{b}}$, Lidwien A.M. Smit ${ }^{\mathrm{c}}$, Rachel Nadif $\mathrm{f}^{\mathrm{a}, \mathrm{b}}$

Affiliations:

${ }^{a}$ Inserm, Centre for research in Epidemiology and Population Health (CESP), U1018, Respiratory and Environmental Epidemiology Team, F-94807, Villejuif, France

${ }^{b}$ Univ Paris-Sud, UMRS 1018, F-94807, Villejuif, France

${ }^{c}$ Division of Environmental Epidemiology, Institute for Risk Assessment Sciences (IRAS),

Utrecht, The Netherlands

\section{Correspondence to}

Marta Rava

Genetic \& Molecular Epidemiology Group

Human Cancer Genetics Program

Spanish National Cancer Research Centre (CNIO)

Melchor Fernández Almagro, 3

28029 Madrid, Spain

Tel. (Lab): +34 912246900 (ext. 3332)

e-mail: marta.rava@inserm.fr (from January 2015: mrava@cnio.es) 


\section{ABTRACT:}

\section{Purpose of review}

Asthma is a complex disease characterized by an intricate interplay of both heritable and environmental factors. Understanding the mechanisms through which genes and environment interact represents one of the major challenges for pulmonary researchers. This review provides an overview of recently published literature on gene-environment (GxE) interactions in asthma, with a special focus on new methodological developments in the post-GWAS era.

\section{Recent findings}

Most recent studies on GxE interaction in asthma used a candidate gene approach. Candidate studies considering exposure to outdoor air pollutants showed significant interactions mainly with variants in the GSTP1 gene on asthma in children. GxE studies on passive and active smoking, including one genome-wide interaction study, identified novel genes of susceptibility to asthma and a time-dependent effect of maternal smoking.

Other recent studies on asthma found interactions between candidate genes and occupational allergen exposure and several domestic exposures such as endotoxin and gas cooking. New methods were developed to efficiently estimate GxE interaction in GWAS, and a pathway-based strategy to select an enriched gene-set for GxE studies has recently been proposed.

\section{Summary}

The GxE studies presented in this review offer a good example on how candidate gene approaches can complement and help in validating GWAS findings.

Keywords (3-5): asthma; environmental exposure; gene-environment interaction; genomewide association studies 


\section{Abbreviations:}

GxE: gene-environment interaction; GWAS: genome-wide association studies; PM: particulate matter; NO2: nitrogen dioxide; O3: ozone; SNP: Single nucleotide polymorphism; ROS: reactive oxygen species; GST: Glutathione S-transferase; ETS: environmental tobacco smoke; GEWIS: genome-wide interaction study

\section{Introduction:}

It is now well established that heritable and environmental factors play a role in asthma pathogenesis. Genetic factors are likely to be involved in the development, the activity and the severity of asthma, and they act primarily through complex mechanisms that involve interactions with environmental factors and with other genes. Gene-environment (GxE) interaction studies aim to explain how the strength and direction of associations between certain genetic variants and asthma may depend on given environmental exposures, and vice versa. So far, most GxE interactions have been identified through hypothesis-driven research involving only few candidate genes (reviewed in [1]). To go further, investigating GxE interactions may help to better understand the role of the genes identified by genome-wide association studies (GWAS) of asthma. For example, variants at chromosome 17q21 that emerged from GWAS have shown particularly strong associations with asthma in children who had had wheezing illnesses or tobacco exposures in early life $\left[2,3^{* *}\right]$. Understanding the mechanisms through which genes and environment interact represents one of the major challenges for pulmonary researchers.

This review will provide an overview of recently published literature (January 2013 to September 2014) on GxE interactions in asthma, with a special focus on new methodological developments in the post-GWAS era. 


\section{Recent findings}

Most recent studies on GxE interaction in asthma used a candidate gene approach (see Table 1). Among the various environmental factors, outdoor air pollution and smoking were the most studied.

\section{Outdoor air pollution exposure}

High levels of outdoor air pollutants such as particulate matter (PM), nitrogen dioxide $\left(\mathrm{NO}_{2}\right)$, and ozone $\left(\mathrm{O}_{3}\right)$ have been associated with a higher risk of asthma [4], mainly in children. Exposure to air pollution can cause oxidative stress and it is plausible that genetic variants involved in inflammation and protection against reactive oxygen species (ROS) may influence the response to air pollutants. Several recent candidate gene studies explored the interactive effect between ambient outdoor pollutants and genes in the Nrf2 (Nuclear factor like 2) antioxidant response pathway. Genes in this pathway, such as those belonging to the Glutathione S-transferase (GST) family (GSTM1, glutathione S-transferase mu 1 and GSTP1, glutathione S-transferase pi 1), and $N Q O 1(N A D(P) H$ dehydrogenase, quinone 1) are responsible for the expression of enzymes that conjugate and inactivate ROS. Interactive effects of variants in the GSTP1 gene with fine particles $\left(\mathrm{PM}_{2.5}\right)$ and $\mathrm{O}_{3}$ were observed on asthma and wheezing in children. Children carrying the rs1695 Ile105Val allele were at increased risk of asthma and wheezing associated with exposure to traffic related $\mathrm{NO}_{2}\left[5^{* *}\right]$, $\mathrm{PM}_{2.5}$ and $\mathrm{O}_{3}[6]$, and at increased risk for asthma if they were exposed to outdoor inhalable coarse particles $\left(\mathrm{PM}_{10}\right)$ [7*]. Interestingly $\mathrm{Su}$ and colleagues [7*] used multifactor dimensionality reduction (MDR) techniques to explore interactions. The joint effect of rs1695 with $\mathrm{O}_{3}$ was observed also on aeroallergen sensitization [8*]. In addition, children carrying 
the minor allele for GSTP1 rs11338272 were more susceptible to have asthma and wheezing when exposed to $\mathrm{NO}_{2}$ when compared to homozygous major allele carriers [5]. Suggestive evidence of an interaction between one single nucleotide polymorphism (SNP; rs2234922) in the EPHX1 (epoxide hydrolase 1) gene and $\mathrm{NO}_{2}$ was also found in children with asthma [7]. Variants involved in immune response, located in genes such as TNFA (tumour necrosis factor alpha) and TLR4 (toll-like receptor 4) seem also to modify the association between exposure to outdoor air pollutants and asthma, as summarized recently by Vawda and colleagues $[9 * *]$.

\section{Smoking exposure}

During the last 18 months, the literature on interaction between genetic variants and smoking exposure provided new insights mostly into early-onset asthma considering parental or maternal smoking during pregnancy or early childhood, and into adult-onset asthma considering current and former smoking. Almost exclusively using a candidate approach, novel genes of susceptibility were suggested that are involved in inflammation, metabolism of xenobiotics, innate immunity, epithelial function, DNA methylation, or belonging to the 17 q21 and 20p13 regions.

Only one genome-wide study of interaction (GEWIS) was conducted [10**] that involved 3048 asthmatics and 3509 non-asthmatics from studies participating in the GABRIEL Consortium. Results from this study suggested the involvement of two novel genes of susceptibility to childhood asthma (age of onset $<16$ years). In particular, it showed suggestive evidence of interactions between: 1) intrauterine tobacco smoke exposure and one SNP located near the gene EPB41L3 (erythrocyte membrane protein band 4.1-like 3, 18p11) that is involved in intercellular junctions, and might play a role in apoptosis and 2) exposure 
to passive smoking in childhood and a SNP localized in PACRG gene (PARK2 co-regulated, 6q25.2-q27), which has a role in morphogenesis and ciliary mobility.

Among Croatian schoolchildren aged 5 to 18 years (423 with asthma and 412 without), Blekic et al. [11*] investigated the increased risk of asthma conferred by $17 \mathrm{q} 12-21$ genetic variants, suggesting the involvement of one novel SNP in the gene IKZF3 (IKAROS family zinc finger 3 ), that is involved in the regulation of lymphocyte development. The authors also reported interaction between genetic variants in ORMDL3 (sphingolipid biosynthesis regulator 3), GSDMA (gasdermin A), GSDMB (gasdermin B), and IKZF3 and early-life environmental tobacco smoke (ETS) exposure in relation to asthma, hospital admissions and lung function. In the same population, Bukvic et al. [12] investigated the increased risk of asthma conferred by 20p13-p12 genetic variants, and showed that the risk was increased by early-life exposure to ETS for six SNPs in ADAM33 (ADAM metallopeptidase domain 33), ATRN (attractin), HSPA12B (heat shock 70kD protein 12B ) and SIGLECl (sialic acid binding Ig-like lectin 1, sialoadhesin) genes. In the study by Li et al. [13], interactive effects between two functional SNPs (rs5491, rs5498) of ICAMI (intercellular adhesion molecule 1, 19p13.3-p13.2) and ETS exposure were studied among elementary-school children in Taiwan. The risk for asthma was significantly higher among children who simultaneously carried the rs5491 AT or TT genotype and the rs5498 GG genotype. Furthermore, the risk for asthma was much higher in children exposed to heavy ETS (at least two household smokers) and carrying the rs5491 AT or TT genotype or the rs5498 GG genotype. Another study that considered intensity of ETS exposure[14], found a weak joint effect of exposure to ETS ( $>5$ versus 0 cigarettes/day in early-life) and one SNP in the gene $C D H 1$ (cadherin 1, type 1, E-cadherin, 16q22) that has an essential role in the formation of epithelial junction. Wu et al. [15**] observed a timedependent interaction between variants in genes from the GST family (GSTP1, GSTM1, GSTT1, glutathione S-transferase theta 1) and maternal smoking in relation to the 
development of wheezing in childhood. Their results suggest that GSTP1 rs1695 A (Ile105) is a risk allele for wheeze, with an effect most clearly seen in children who are exposed to maternal smoking, and only observed for early-life wheezing. In a study based on all liveborn twins in Denmark between 1994 and 2000 [16], maternal smoking during pregnancy increased the risk of asthma by $70 \%$ in the offspring, but no evidence of genetic effect modification was observed as only $3 \%$ change in the heritability of asthma was observed in children whose mothers smoked during pregnancy compared with children of non-smoking mothers.

Among 1085 unrelated individuals with asthma and an onset of asthma at or after two years of age, Ferry et al. [17] investigated interactions between 26 selected SNPs from GWAS and parental and maternal smoking behaviour on age of asthma onset. The strongest interactions were observed between rs9500927 in HLA-DOA (major histocompatibility complex, class II, DO alpha, 6p21.3) and paternal smoking, and between rs10508372 in LOC338591 (coiledcoil-helix-coiled-coil-helix domain containing 3 pseudogene, 10p14) and both paternal smoking and direct exposure to paternal smoking. The authors also reported interaction between rs4129267 in IL6R (Interleukin 6 receptor, 1q21) and carpet exposure. There were no significant GxE interactions after correction for multiple testing.

In adults, one study [18] reported an interaction between IL3 rs40401 (Interleukin 3 (colonystimulating factor, multiple), 5q23-q31) and ever smoking (at least once per day for at least one year) on the risk of asthma in 89 cases and 700 healthy young Japanese women.

Overall, recent gene by smoking interaction studies on asthma in adults are scarce. Recent findings add to the body of evidence that maternal/parental smoking during pregnancy and in childhood increases the risk of asthma, involving both direct effects and interactive effects with genetics that may vary with time. Indeed, time is a factor known to play a major role in the pathophysiology of asthma, so extending research from two-dimensional GxE to three- 
dimensional gene-environment-time interactions may help in discovering novel GxE interactions.

\section{Other environmental exposures}

Several recent studies investigated interactions between candidate genes and other environmental factors associated with asthma, such as occupational allergen exposure, prenatal alcohol exposure, and indoor exposures (endotoxin, mould, gas cooking and household carpet use).

Evidence from several independent GWAS lends support to the involvement of HLA-II loci in asthma, in particular among adults. Imputed common HLA-II alleles were not associated per se with adult-onset asthma in a meta-analysis of more than 6,000 European subjects from cohorts participating in the GABRIEL GWAS [19**]. However, when taking occupational allergen exposures into account, results suggested a GxE interaction between the $D P B 1 * 03: 01$ allele and occupational exposure to latex.

Using a Mendelian randomization approach, Shaheen et al. [20**] did not find evidence to suggest that alcohol consumption in pregnancy increases the risk of childhood atopic disease. A maternal $A D H 1 B$ (alcohol dehydrogenase) variant (rs1229984), as a proxy for prenatal alcohol exposure, was unrelated to childhood asthma and other atopic outcomes. Moreover, there was no interaction between maternal $A D H 1 B$ and reported intake of alcohol in pregnancy.

The complex, but well-described interaction between CD14 (cluster of differentiation 14) variants and endotoxin exposure levels was illustrated again recently among patients with asthma. This study observed significant interactions between variants in the endotoxin pathway (LY69, lymphocyte antigen 96 and CD14) and endotoxin exposure in relation to repeated hospital admissions [21]. However, in the first GEWIS on asthma, Ege et al. did not 
identify any statistically significant interactions with farm exposures at the genome-wide level [22]. Moreover, they did not confirm interactions with SNPs in candidate genes, such as $C D 14$, even when a less stringent significance threshold was applied. House dust endotoxin levels were not studied in the GEWIS, which may explain the discrepancy with other findings.

Gas cooking is a major indoor source of the highly oxidant $\mathrm{NO}_{2}$. In adults from the multicentre European Community Respiratory Health Survey, increased bronchial responsiveness was associated with gas cooking, but only among subjects with the GSTM1 null genotype [23**]. A meta-analysis of six birth cohorts found statistically significant effects of early exposure to mould or dampness on early wheezing and nasal symptoms, but there was no evidence of a GxE interaction between GSTP1 (rs1695) and mould exposure [24*]. Household carpet use is known to be a reservoir of major indoor allergens, which may increase airway inflammation and asthma in children. In the population-based Taiwan Children Health Study, household carpet use appeared to modify the effects of $I L-13$ variants on wheeze and late-onset asthma [25*].

\section{Methods in gene-environment interaction studies}

The GxE studies presented in this review offer a good example on how candidate gene approaches can complement and help in validating GWAS findings. In fact, thanks to the availability of results from GWAS, new hypotheses were tested including genes implicated in previously unexplored biological pathways in the study of asthma. Up to now only two GEWIS on asthma have been conducted [10**,21], that identified overall only two statistically significant interactions. One of the reasons why GEWIS were less successful than the candidate approach in identifying GxE interactions is related to the large number of tests that need to be performed, which in turn requires stringent thresholds in order to declare a 
GxE interaction significant. Research is moving on to new methods that efficiently estimate interactions [25**]. As an example, Hancock and colleagues [27] showed that joint testing of SNP and SNP-by-environment interaction identified novel loci associated with complex traits (e.g. pulmonary function) that are missed when considering only the genetic main effects. Lack of replication in GEWIS may reflect also heterogeneity in environmental exposure assessment as well as in outcome definition. Large consortia of epidemiologic studies with well-characterized exposure data and standardized outcome definition are warranted to exploit the potential of GxE interaction studies.

An alternative between the candidate and the "agnostic" approach of GWAS is provided by the pathway-based approach, in which several genes related to the biological pathways of interest are studied. An enriched gene-set selection strategy that integrates the information on biological processes shared by genes, the canonical pathways to which they belong, and knowledge of the environmental factor has recently been proposed [28*]. Rare genetic variant association, together with GxE interaction studies is believed to be another important contributor to missing heritability [29]. Thanks to the advent of next generation sequencing technologies and whole exome arrays, it is now possible to genotype rare variants at relatively low cost. Since the power of traditional methods to detect GxE interactions is expected to be low, specialized association tests and methodologies are now being developed [30].

Together with GxE interaction, gene-gene interactions, or epistasis, and epigenetic effects are believed to be of great importance for the development of complex diseases. In particular, recent findings support the hypothesis that gene-environment interactions in asthma are mediated, at least in part, by epigenetic processes, such as DNA-methylation (see the review by Kabesch [31**]). Numerous studies have also provided evidence that both intestinal and airway microbiome, and their alteration may contribute to chronic asthma (reviewed in $\left[32^{*}\right]$ ), offering new routes of research into the understanding of GxE interactions. The integration of 
genetic, epigenetic and microbiome data may help in clarifying the complex mechanism of asthma pathogenesis.

\section{CONCLUSION}

This review shows that most recent GxE interaction studies followed a candidate gene approach and only one recent GEWIS study exists on asthma. Research in genetics of complex diseases is moving toward increasingly detailed data. Nevertheless the success of post-GWAS era studies in asthma will depend also on the effort put in adequate quantification of environmental exposure and standardization in sample collection as well as phenotype definition. Novel genes of susceptibility to asthma were revealed only when relevant environmental exposures were considered. Therefore, it could be envisaged that detecting GxE interactions may help to target preventive strategies in susceptible individuals.

\section{Key bullet points}

Key bullet point 1: Candidate gene-environment interaction studies on asthma may help to better understand the role of the genes identified by genome-wide association studies.

Key bullet point 2: Variants in the GSTP1 and GSTM1 gene modify the association of exposure to traffic-related outdoor air pollution, tobacco smoke exposure, and gas cooking with asthma outcomes in children and adults.

Key bullet point 3: Gene-smoking interaction studies add further evidence that passive smoking during pregnancy and in childhood increases the risk of asthma, with an effect that varies with intensity of exposure and time, and is more pronounced in children carrying genetic variants that increase susceptibility.

There are no conflicts of interest. 


\section{References}

1. Kauffmann F, Demenais F. Gene-environment interactions in asthma and allergic diseases: challenges and perspectives. J Allergy Clin Immunol. Elsevier Ltd; 2012 Dec;130(6):1229-40;

2. Smit LAM, Bouzigon E, Pin I, et al. 17q21 variants modify the association between early respiratory infections and asthma. Eur Respir J. 2010 Jul;36(1):57-64.

3. **Calışkan M, Bochkov YA, Kreiner-Møller E, et al. Rhinovirus wheezing illness and genetic risk of childhood-onset asthma. N Engl J Med. 2013 Apr 11;368(15):1398407.

Results from two birth cohorts confirm that $17 q 21$ genetic variants may modify associations between viral infections and asthma. Variants at the 17q21 locus were associated with asthma in children who had had HRV wheezing illnesses and with expression of two genes at this locus.

4. Guarnieri M, Balmes JR. Outdoor air pollution and asthma. Lancet. 2014 May 3;383(9928):1581-92.

5. **MacIntyre EA, Brauer M, Melén E, et al. GSTP1 and TNF Gene variants and associations between air pollution and incident childhood asthma: the traffic, asthma and genetics (TAG) study. Environ Health Perspect. 2014 Apr;122(4):418-24.

A study that shows interaction between variants in the GSTP1 genes and exposure to $\mathrm{NO}_{2}$ on asthma in children from six birth cohort studies

6. Hwang B, Young L, Tsai C, et al. Fine Particle, Ozone Exposure, and Asthma/Wheezing: Effect Modification by Glutathione S-transferase P1 Polymorphisms. PLoS One. 2013;8(1):1-7. 
7. *Su MW, Tsai CH, Tung KY, et al. GSTP1 is a hub gene for gene-air pollution interactions on childhood asthma. Allergy. 2013 Dec;68(12):1614-7.

GxE interaction detected with a multifactor dimensionality reduction approach

8. *Fuertes E, Brauer M, MacIntyre E, et al. Childhood allergic rhinitis, traffic-related air pollution, and variability in the GSTP1, TNF, TLR2, and TLR4 genes: results from the TAG Study. J Allergy Clin Immunol. 2013 Aug;132(2):342-52.e2.

A study the explored interactions between exposure to traffic related air pollutants and candidate genes on allergic rhinitis and allergic sensitization in children from six birth cohort studies

9. **Vawda S, Mansour R, Takeda A, et al. Associations between inflammatory and immune response genes and adverse respiratory outcomes following exposure to outdoor air pollution: A huge systematic review. Am J Epidemiol. 2014;179(4):432_42.

Comprehensive review that report evidence for an association between SNPs in inflammatory and immune response genes and adverse respiratory outcomes from exposure to outdoor air pollution

10. **Scholtens S, Postma DS, Moffatt MF, et al. Novel childhood asthma genes interact with in utero and early-life tobacco smoke exposure. J Allergy Clin Immunol. 2014 Mar;133(3):885-8.

This study on childhood asthma is the first hypothesis-free GWIS specifically aiming to identify SNPs that interact with tobacco smoke exposure in disease development. Suggestive evidence for an interaction between rs8094633 near EPB41L3 and in utero tobacco smoke exposure, and an interaction between rs 1575472 in PACRG and childhood tobacco smoke 
exposure were found. These SNPs have not been identified previously in general genome-wide association studies on childhood asthma.

11. *Blekic M, Kljaic Bukvic B, Aberle N, et al. 17q12-21 and asthma: Interactions with early-life environmental exposures. Ann Allergy, Asthma Immunol. American College of Allergy, Asthma \& Immunology; 2013;110(5):347-53.

Significant interactions between polymorphisms in the 17q12-21 region with ETS exposure on asthma were found in children providing further evidence that this region is associated with asthma. Furthermore, among children with asthma, similar interactions with respect to severe asthma exacerbations requiring hospital admission and the level of lung function were observed.

12. Kljaic-Bukvic B, Blekic M, Simpson A, et al. Asthma severity, polymorphisms in 20p13 and their interaction with tobacco smoke exposure. Pediatr Allergy Immunol. 2013 Feb;24(1):10-8.

13. Li Y-F, Lin C-C, Tai C-K. Interaction of Intercellular Adhesion Molecule 1 (ICAM1) Polymorphisms and Environmental Tobacco Smoke on Childhood Asthma. Int J Environ Res Public Health. 2014 Jun 20;11(6):6504-16.

14. Wang M-F, Kuo S-H, Huang C-H, et al. Exposure to environmental tobacco smoke, human E-cadherin C-160A polymorphism, and childhood asthma. Ann Allergy Asthma Immunol. American College of Allergy, Asthma \& Immunology; 2013 Oct;111(4):262-7.

15. **Wu J, Hankinson J, Kopec-Harding K, et al. Interaction between glutathione Stransferase variants, maternal smoking and childhood wheezing changes with age. Pediatr Allergy Immunol. 2013 Aug;24(5):501-8. 
In a birth cohort study, interactions between maternal smoking and GST variants on wheezing during the first 11 yr of life were investigated. Results provide evidence that children carrying GSTP1 rs1695 AA may be more susceptible to the effects of maternal smoking with regard to the development of wheeze at a young age, and that the effect of maternal smoking on wheezing diminishes with time.

16. Kahr N, Naeser V, Stensballe LG, et al. Gene-environment interaction in atopic diseases: a population-based twin study of early-life exposures. Clin Respir J. 2014 Jan $21 ; 1-8$.

17. Ferry OR, Duffy DL, Ferreira MAR. Early life environmental predictors of asthma age-of-onset. Immunity, Inflamm Dis. 2014 Jul 26;

18. Miyake Y, Tanaka K, Arakawa M. IL3 rs40401 polymorphism and interaction with smoking in risk of asthma in Japanese women: the Kyushu Okinawa Maternal and Child Health study. Scand J Immunol. 2014 Jun 31;79(6):410-4.

19. *Smit LAM, Strachan DP, Vermeulen R, et al. Human leukocyte antigen class II variants and adult-onset asthma: does occupational allergen exposure play a role? Eur Respir J. 2014 Jul 17;

The HLA-II region emerged from several GWAS of late-onset asthma. This study further investigated the role of HLA-II in adult-onset asthma, by imputation of classical HLA-II alleles. A modest GxE interaction with occupational allergen exposures was found.

20. **Shaheen SO, Rutterford C, Zuccolo L, Ring SM, Davey Smith G, Holloway JW, Henderson AJ. Prenatal alcohol exposure and childhood atopic disease: a Mendelian randomization approach. J Allergy Clin Immunol. 2014 Jan;133(1):225-32.e1-5. 
This excellent analysis in the large population-based ALSPAC birth cohort used a Mendelian randomization approach to study the relation between prenatal alcohol exposure and atopic phenotypes. This approach, which minimizes bias and confounding, did not provide evidence to suggest that prenatal alcohol exposure increases the risk of asthma or atopy in childhood.

21. *Kljaic-Bukvic B, Blekic M, Aberle N, et al. Genetic variants in endotoxin signalling pathway, domestic endotoxin exposure and asthma exacerbations. Pediatr Allergy Immunol. 2014 Jun 5;

Variants in the endotoxin pathway (LY96 and CD14) and domestic endotoxin exposure showed a significant interaction in relation to repeated hospital admissions in children with asthma.

22. Ege MJ, Strachan DP, Cookson WOCM, et al. Gene-environment interaction for childhood asthma and exposure to farming in Central Europe. J Allergy Clin Immunol. 2011 Jan;127(1):138-44, 144.e1-4.

23. **Amaral AFS, Ramasamy A, Castro-Giner F, et al. Interaction between gas cooking and GSTM1 null genotype in bronchial responsiveness: results from the European Community Respiratory Health Survey. Thorax. 2014 Jun 10;69(6):558-64.

Convincing GxE interaction study in adults from ECRHS, showing that gas cooking and increased bronchial responsiveness are related, but only among susceptible subjects with the GSTM1 null genotype.

24. *Tischer CG, Gref A, Standl M, et al. Glutathione-S-transferase P1, early exposure to mould in relation to respiratory and allergic health outcomes in children from six birth cohorts. A meta-analysis. Allergy. 2013 Mar;68(3):339-46. 
Large meta-analysis, that did not demonstrate evidence for GxE interaction between GSTP1 and domestic mould exposure in young children.

25. *Tsai C-H, Tung K-Y, Su M-W, et al. Interleukin-13 genetic variants, household carpet use and childhood asthma. PLoS One. 2013 Jan;8(1):e51970.

GXE analysis that provides evidence of an interaction between household carpet use and IL13 variants on wheeze and late-onset asthma in Taiwanese children.

26. **Gauderman WJ, Zhang P, Morrison JL, et al. Finding novel genes by testing $\mathrm{G} \times \mathrm{E}$ interactions in a genome-wide association study. Genet Epidemiol. 2013 Sep;37(6):603-13.

This study proposes a new method to detect GxE interactions and provides an overview of the common statistical approaches for GEWIS

27. Hancock D, Artigas M, Gharib S. Genome-wide joint meta-analysis of SNP and SNPby-smoking interaction identifies novel loci for pulmonary function. PLoS Genet. 2012 Jan;8(12):e1003098.

28. *Rava M, Ahmed I, Demenais F, et al. Selection of genes for gene-environment interaction studies: a candidate pathway-based strategy using asthma as an example. Environ Health. 2013 Jan;12:56.

Pathway-based strategy, to select enriched gene-set for gene-environment studies

29. Thomas D. Methods for investigating gene-environment interactions in candidate pathway and genome-wide association studies. Annu Rev Public Health. 2010 Jan;31(103):21-36. 
30. Kazma R, Cardin N, Witte J. Does Accounting for Gene-Environment Interactions Help Uncover Association between Rare Variants and Complex Diseases? Hum Hered. 2013;205-14.

31. **Kabesch M. Epigenetics in asthma and allergy. Curr Opin Allergy Clin Immunol. $2014 \mathrm{Feb} ; 14(1): 62-8$.

Recommended review that gives an overview on recent developments in the field of asthma and allergy epigenetics with a special focus on the role of DNA methylation.

32. *Daley D. The evolution of the hygiene hypothesis: the role of early-life exposures to viruses and microbes and their relationship to asthma and allergic diseases. Curr Opin Allergy Clin Immunol. 2014 Aug 7;

Review paper that provides new ways in which viral and microbial exposures in early life interact with host genetics to modify the risk for developing asthma and allergic diseases. 
Table 1: Recent GxE interaction studies on asthma highlighting study characteristics and major findings

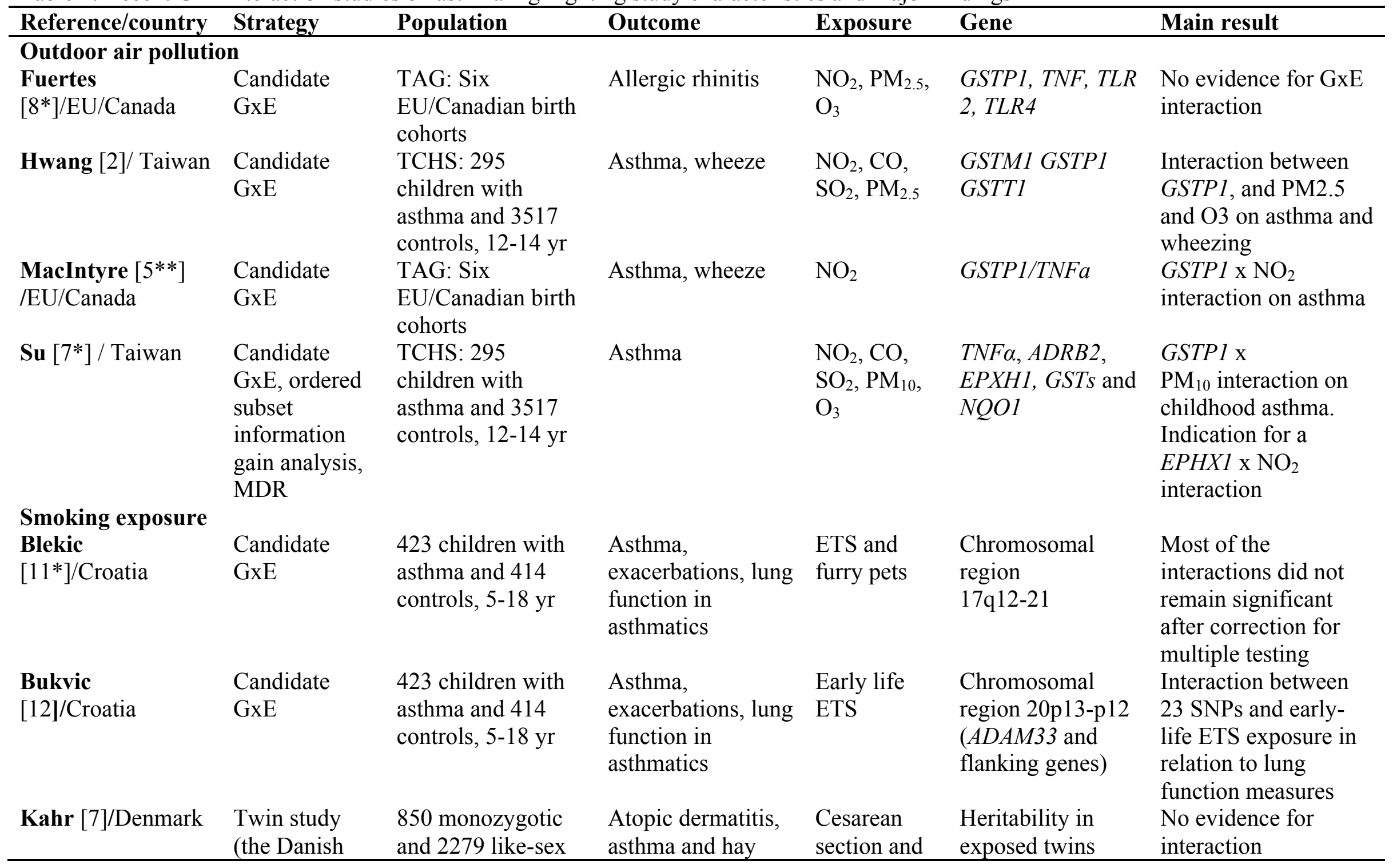




\begin{tabular}{|c|c|c|c|c|c|c|}
\hline & $\begin{array}{l}\text { Twin } \\
\text { Registry) }\end{array}$ & $\begin{array}{l}\text { dizygotic twin } \\
\text { pairs, 3-9 yr }\end{array}$ & fever & $\begin{array}{l}\text { in utero } \\
\text { exposure to } \\
\text { passive } \\
\text { smoking }\end{array}$ & $\begin{array}{l}\text { compared with } \\
\text { unexposed twins }\end{array}$ & \\
\hline Li [8]/Taiwan & $\begin{array}{l}\text { Candidate } \\
\text { GxE }\end{array}$ & $\begin{array}{l}218 \text { children with } \\
\text { asthma and } 877 \\
\text { controls (school- } \\
\text { aged) }\end{array}$ & Asthma & $\begin{array}{l}\text { Maternal } \\
\text { smoking and } \\
\text { numbers of } \\
\text { household } \\
\text { smokers }\end{array}$ & $\begin{array}{l}I C A M I(\mathrm{rs} 5491 \\
\text { and rs5498, and } \\
\text { haplotypes) }\end{array}$ & $\begin{array}{l}\text { Interaction between } \\
\text { rs5491 or rs } 5498 \text { and } \\
\text { heavy ETS on asthma }\end{array}$ \\
\hline Miyake [9]/Japan & $\begin{array}{l}\text { Candidate } \\
\text { GxE }\end{array}$ & $\begin{array}{l}\text { Prospective } \\
\text { prebirth cohort } \\
\text { (KOMCHS): } 89 \\
\text { women with } \\
\text { asthma and } 700 \\
\text { controls (mean } \\
\text { age }=30 \mathrm{yr} \text { ) }\end{array}$ & Current asthma & $\begin{array}{l}\text { Ever } \\
\text { smoking }\end{array}$ & IL3 (rs40401) & $\begin{array}{l}\text { Individuals with the } \\
\text { CC genotype who had } \\
\text { ever smoked had a } \\
2.67 \text {-fold increased } \\
\text { risk of asthma in } \\
\text { comparison with } \\
\text { those with at least one } \\
\text { T allele who had } \\
\text { never smoked }\end{array}$ \\
\hline $\begin{array}{l}\text { Scholtens } \\
{\left[10^{* *}\right] / \text { Europe }}\end{array}$ & GEWIS & $\begin{array}{l}\text { Discovery samples: } \\
3,048 \text { cases and } \\
3,509 \text { control } \\
\text { subjects derived } \\
\text { from } 9 \text { studies } \\
\text { (GABRIEL } \\
\text { consortium). } \\
\text { Replication } \\
\text { samples: } 4 \\
\text { independent studies } \\
\text { including more } \\
\text { than } 13,000 \\
\text { subjects }\end{array}$ & $\begin{array}{l}\text { Childhood-onset } \\
\text { asthma }\end{array}$ & $\begin{array}{l}\text { In utero and } \\
\text { childhood } \\
\text { tobacco } \\
\text { smoke }\end{array}$ & 538,233 SNPs & $\begin{array}{l}\text { Interaction between in } \\
\text { utero exposure and } \\
\text { rs } 8094633 \text { near } \\
E P B 41 L 3 \text {, and } \\
\text { between rs } 1575472 \\
\text { near } P A C R G \text { and } \\
\text { childhood tobacco } \\
\text { exposure }\end{array}$ \\
\hline Wang [11]/Taiwan & Candidate & 299 children with & Asthma & Household & $C D H 1, M M P-3$, & Some evidence for \\
\hline
\end{tabular}




\begin{tabular}{|c|c|c|c|c|c|c|}
\hline & GxE & $\begin{array}{l}\text { asthma and } 383 \\
\text { healthy controls, } 5- \\
12 \mathrm{yr}\end{array}$ & & $\begin{array}{l}\text { smoking, } \\
\text { number of } \\
\text { cigarettes } \\
\text { smoked by } \\
\text { the parents, } \\
\text { duration of } \\
\text { exposure }\end{array}$ & and $T I M P-1$ & $\begin{array}{l}\text { interaction between } \\
\mathrm{CDH1} \mathrm{C}-160 \mathrm{~A} \text { and } \\
\text { more ETS exposure }\end{array}$ \\
\hline $\mathbf{W u}\left[15^{* *}\right] / \mathrm{UK}$ & $\begin{array}{l}\text { Candidate } \\
\text { GxE, follow- } \\
\text { up }\end{array}$ & $\begin{array}{l}807 \text { children }(1-11 \\
\text { years old) }\end{array}$ & $\begin{array}{l}\text { Ever/current } \\
\text { wheeze }\end{array}$ & $\begin{array}{l}\text { Maternal } \\
\text { current } \\
\text { smoking at } \\
\text { each follow- } \\
\text { up }(1,3,5,8 \\
\text { and } 11 \mathrm{yr}) \\
\text { and ETS } \\
\text { exposure in } \\
\text { infancy } \\
\text { (birth or age } \\
1 \text { yr) }\end{array}$ & $\begin{array}{l}\text { GSTP1, GSTT1 } \\
\text { and GSTM1 }\end{array}$ & $\begin{array}{l}\text { The risk of wheezing } \\
\text { in the first year of life } \\
\text { was significantly } \\
\text { increased in GSTP1 } \\
\text { (rs1695, functional) } \\
\text { AA homozygotes, but } \\
\text { only if their mothers } \\
\text { smoked }\end{array}$ \\
\hline $\begin{array}{l}\text { Ferry } \\
\text { [13]/Australia }\end{array}$ & $\begin{array}{l}\text { Candidate } \\
\text { GxE }\end{array}$ & $\begin{array}{l}1085 \text { subjects with } \\
\text { physician- } \\
\text { diagnosed asthma } \\
\text { and disease onset at } \\
\text { or after age two }\end{array}$ & $\begin{array}{l}\text { Asthma age-of- } \\
\text { onset }\end{array}$ & $\begin{array}{l}\text { Parental and } \\
\text { maternal } \\
\text { smoking } \\
\text { behaviors, } \\
\text { household } \\
\text { exposure to } \\
\text { pets and } \\
\text { carpet }\end{array}$ & $\begin{array}{l}26 \text { SNPs that have } \\
\text { been associated } \\
\text { with the risk of } \\
\text { asthma or other } \\
\text { allergic diseases } \\
\text { in GWAS at the } \\
\text { genome-wide } \\
\text { significance level }\end{array}$ & $\begin{array}{l}\text { No evidence of } \\
\text { interaction after } \\
\text { correction for } \\
\text { multiple testing }\end{array}$ \\
\hline \multicolumn{7}{|c|}{ Other environmental exposures } \\
\hline $\begin{array}{l}\text { Amaral } \\
{[23 * *] / \text { Europe }}\end{array}$ & $\begin{array}{l}\text { Candidate } \\
\text { GxE }\end{array}$ & $\begin{array}{l}\text { ECRHS II: } 2208 \\
\text { European adults } \\
\text { with complete data } \\
\text { on BHR and } \\
\text { GSTMI }\end{array}$ & BHR & $\begin{array}{l}\text { Using gas } \\
\text { for cooking }\end{array}$ & $\begin{array}{l}\text { GSTM1 GSTP1 } \\
\text { GSTT1 }\end{array}$ & $\begin{array}{l}\text { Increased bronchial } \\
\text { responsiveness was } \\
\text { associated with gas } \\
\text { cooking among } \\
\text { subjects with the }\end{array}$ \\
\hline
\end{tabular}




\begin{tabular}{|c|c|c|c|c|c|c|}
\hline $\begin{array}{l}\text { Caliskan }\left[3^{* *}\right] / \\
\text { USA, Denmark }\end{array}$ & $\begin{array}{l}\text { Candidate } \\
\text { GxE }\end{array}$ & $\begin{array}{l}\text { COAST: } 200 \\
\text { children, } 6-8 \text { yr and } \\
\text { COPSAC: } 297 \\
\text { children, } 7 \text { yr }\end{array}$ & Asthma & $\begin{array}{l}\mathrm{HRV} / \mathrm{RSV} \\
\text { wheezing } \\
\text { illness }\end{array}$ & $\begin{array}{l}\text { chromosomal } \\
\text { region } 17 \mathrm{q} 21\end{array}$ & $\begin{array}{l}\text { GSTM1 null } \\
\text { genotype. } \\
\text { GE HRV and } 17 \mathrm{q} 21\end{array}$ \\
\hline $\begin{array}{l}\text { Kljaic-Bukvic } \\
{\left[20^{*}\right] / \text { Croatia }}\end{array}$ & $\begin{array}{l}\text { Candidate } \\
\text { GxE }\end{array}$ & $\begin{array}{l}417 \text { subjects with } \\
\text { asthma, } 407 \\
\text { controls; (age 5-18 } \\
\text { years) }\end{array}$ & $\begin{array}{l}\text { Hospitalization for } \\
\text { asthma } \\
\text { exacerbations }\end{array}$ & $\begin{array}{l}\text { Endotoxin } \\
\text { exposure }\end{array}$ & $\begin{array}{l}\text { CD14, LY96 and } \\
\text { TLR4 }\end{array}$ & $\begin{array}{l}\text { Evidence for } \\
\text { interaction between } \\
\text { the SNP rs } 2915863 \\
\text { (CD14) and the SNP } \\
\text { rs17226566 (in } \\
\text { LY96) and endotoxin } \\
\text { exposure on hospital } \\
\text { admission due to } \\
\text { asthma exacerbation }\end{array}$ \\
\hline Smit $[19 *] /$ Europe & $\begin{array}{l}\text { Candidate } \\
\text { GxE }\end{array}$ & $\begin{array}{l}6,025 \text { adults from } \\
\text { ECRHS, Sapaldia, } \\
\text { EGEA, B58C and } \\
\text { occupational } \\
\text { cohorts }\end{array}$ & Adult onset asthma & $\begin{array}{l}\text { Occupationa } \\
1 \text { exposure } \\
\text { to high } \\
\text { molecular } \\
\text { weight } \\
\text { allergens }\end{array}$ & $H L A-I I$ & $\begin{array}{l}\text { Modest interaction } \\
\text { between DPB }{ }^{*} 03: 01 \\
\text { allele and } \\
\text { occupational allergen } \\
\text { exposure, in particular } \\
\text { latex exposure }\end{array}$ \\
\hline $\begin{array}{l}\text { Tischer }[24 *] / \text { Euro } \\
\text { pe }\end{array}$ & $\begin{array}{l}\text { Candidate } \\
\text { GxE }\end{array}$ & $\begin{array}{l}\text { 14,595 children } \\
\text { from LISAplus, } \\
\text { GINIplus, } \\
\text { BAMSE, PIAMA, } \\
\text { CAPPS or } \\
\text { ALSPAC }\end{array}$ & $\begin{array}{l}\text { Early wheezing, } \\
\text { early asthma } \\
\text { symptom complex } \\
\text { school-age asthma } \\
\text { symptom complex } \\
\text { nasal symptoms, } \\
\text { rhinoconjunctivitis, } \\
\text { and allergic } \\
\text { sensitization. }\end{array}$ & $\begin{array}{l}\text { Parent- } \\
\text { reported } \\
\text { mould } \\
\text { and/or } \\
\text { dampness in } \\
\text { any room of } \\
\text { the home } \\
\text { during the } \\
\text { first } 2 \text { years } \\
\text { of life }\end{array}$ & GSTP1 & $\begin{array}{l}\text { No significant } \\
\text { interaction }\end{array}$ \\
\hline Tsai $[25 *] /$ Taiwan & Candidate & TCHS, 3577 & Asthma & Carpet & IL 13 & IL13 haplotype $\mathrm{x}$ \\
\hline
\end{tabular}




\begin{tabular}{llll}
\hline GxE & children & phenotypes & $\begin{array}{l}\text { (indoor } \\
\text { allergens) }\end{array}$ \\
& & $\begin{array}{l}\text { carpet interaction for } \\
\text { late onset asthma and } \\
\text { wheeze }\end{array}$
\end{tabular}

TCHS: Taiwan Children Health Study, TAG: Traffic, Asthma, and Genetics; MDR: multifactor dimensionality reduction; ETS: environmental tobacco smoke 